Parody and Pedagogy: Explorations in Imitative Literature Author(s): John J. Ruszkiewicz

Source: College English, Vol. 40, No. 6 (Feb., 1979), pp. 693-701

Published by: National Council of Teachers of English

Stable URL: http://www.jstor.org/stable/375973

Accessed: 09-08-2016 17:10 UTC

\title{
REFERENCES
}

Linked references are available on JSTOR for this article:

http://www.jstor.org/stable/375973?seq=1\&cid=pdf-reference\#references_tab_contents You may need to log in to JSTOR to access the linked references.

Your use of the JSTOR archive indicates your acceptance of the Terms \& Conditions of Use, available at

http://about.jstor.org/terms

JSTOR is a not-for-profit service that helps scholars, researchers, and students discover, use, and build upon a wide range of content in a trusted digital archive. We use information technology and tools to increase productivity and facilitate new forms of scholarship. For more information about JSTOR, please contact support@jstor.org.

National Council of Teachers of English is collaborating with JSTOR to digitize, preserve and extend access to College English 


\section{Parody and Pedagogy: Explorations in Imitative Literature}

STUDENTS ARE OFTEN ENCOURAged To wRITE parodies as a way of expanding or testing their familiarity with the form and subject matter of a given work or author. In these productions, the more ambitious and intelligent students are expected to move into the area of criticism, examining an original by foisting on its familiar form a subject matter and point of view that jolt the reader onto a more discriminating level of appreciation, or a more jaundiced one. Yet on occasion, students assigned to write parodies for instructional reasons unwittingly turn into parodists; that is, in a minor key they become artists themselves and produce imitative works that do not always fulfill the expectations (or directions) of the instructor. Such reflections on an original may distort the form but fail to criticize the major work, or they may maintain the form and launch an attack on some target other than the original. Neither of these tactics (just two of many possible variations) is necessarily outside the realm of parody. But the instructor who regards parody as essentially an act of literary criticism is likely to be disappointed with students whose imitative efforts do not rebuke Tennyson for his pomposity or Browning for his confusing syntax. However, these same students may actually be mining a parodic vein as yet undiscovered by the instructor. ${ }^{1}$

Any piece of art, any poetic text-as a representation of reality-is incomplete. No matter how great or visionary a work may be, we can imagine the application of its form to a new and inventive subject matter (however inappropriate), or we can project the original subject matter onto a different form. Perhaps the only compositions that could not be so transformed or parodied would be those that represent human experience absolutely and which can be experienced in that totality. In some sense, The Canterbury Tales or The Complete Works of Shakespeare approach this ideal and, hence, would resist parody because they include within themselves nearly all human impulses-including the anarchic, introspective, and often festive one that prompts imitation and mimicry. Indeed, Chaucer's tales are sometimes arranged to

\footnotetext{
${ }^{1}$ Many theorists regard an element of literary criticism as the sine qua non of "true" or "perfect" parody - a questionable view. See J. G. Riewald, "Parody as Criticism," Neopbilologus, 50 (1966), 125-33, for one such formulation.
}

Jobn J. Ruszkiewicz is an assistant professor of English at the University of Texas at Austin, where be teaches Shakespeare and a variety of writing courses in addition to the survey course which provided the materials for bis article. 
trap parodic energies, The Knight's Tale being waylaid by the Miller's, which in turn stumbles over the Reeve's. So too the Shakespeare canon, treated as an entity, becomes gibe-proof; or to put it another way, it anticipates parodic reaction by commenting on itself: the follies of young love in Romeo and Juliet are balanced by the tribulations of mature passion in Antony and Cleopatra, while the sublime rages of Lear are reduced to rantings by Timon of Athens. Even within Romeo and Juliet the attitude toward love of Mercutio parodies that of Romeo, and comedies like As You Like It parody themselves.

In practice, we cannot deal with totalities of vision, even when offered by a Chaucer or a Shakespeare: parts of the whole break away, the unfamiliar language becomes a discrete component, and these masters, too, succumb to parody. Or more accurately, are complemented by it. For as G. D. Kiremidjian asserts in an article that examines the theory of the genre, parody is the most "art-conscious" of aesthetic exercises and, by implication, a creative one. ${ }^{2}$ Because no work is absolute and because human consciousness delights in plenitude, in filling out all the possibilities of a form and subject matter, parodists-even though they imitate-are by nature creators since they expand a vision to worlds unexplored and unanticipated by the original artist. ${ }^{3}$ Yet not all alien worlds are hostile, nor all parodies critical or risible. The uninstructed nature of imitative literature encourages free and inventive explorations of form and subject matter that sometimes-even ordinarily-result in criticism and humor. But these are aspects of parody, not definitions of it. ${ }^{4}$ So that students expected to produce critical parodies, following the nature of parody itself, will as often as not fail to criticize or ridicule an original, yet succeed in establishing some other instructive relationship between the major work and their imitative exploration of it.

Let me demonstrate what I mean about the range of parody by quoting selectively from a single set of themes produced by a class which had been given the option of writing a parody in lieu of a final term paper. The course was a survey of English literature from Blake to the moderns, ordinarily taken by sophomores, but my class included a number of freshmen and juniors. Occasionally during the semester I had dipped into the six volumes of Walter Hamilton's Parodies of the Works of English and American Authors (1884-1889), so that the class was exposed to the genre. But, aside from the direction and encouragement given in the assignment, students had not been told how to produce imitative works:

Write a parody of a work or works of an author we have studied since (and including) Tennyson. Then write an essay explaining how your parody reflects the characteristic themes, habits, diction, style (etc.) of your chosen author.

Be sure to parody a substantial work, not a four-line lyric. And don't be surprised if your parody gets out of hand and develops into something you hadn't quite expected.

\footnotetext{
2"The Aesthetics of Parody," Journal of Aesthetics and Art Criticism, 28 (1969/70), 231-42.

${ }^{3}$ The humor that frequently informs parody is the result of seeing something familiar in a new and unexpected way. G. B. Milner, writing on a more general topic, suggests that laughter may be "ultimately based on linguistic reversal and transportation" ("Homo Ridens, Towards a Semiotic Theory of Humour and Laughter," Semiotica, 5 [1972], 27). Simple reversal, of course, does not explain the mechanics of all parody, but the notion of "transportation" is valuable in explaining what happens to the original work in a parodic relationship.

${ }^{4}$ See Rosemary Freeman, "Parody as a Literary Form: George Herbert and Wilfred Owen," Essays in Criticism, 13 (1963), 307-22, for examples of parodies not given to either satire or humor.
} 
Not only will you then have more to write about, but you will have made a discovery about parodies.

Three other choices were offered, but more than half the class attempted parody.

From the twenty-two works produced by this single group, I have been able to identify and describe at least eight categories of imitative literature, ranging from the frankly derivative to the artistically independent. I do not mean to imply that this roster represents an exhaustive catalogue of parodic types. Far from it. The significance in these variations, both critically and pedagogically, resides in the power of a literary work to produce an assortment of responses and in the ability of students not only to recognize such responses, but to create them. In short, parody gives the instructor a way of infusing a work (particularly an older piece) with an energy it may lack, lying flat, anthologized, in a book.

Predictably, several students wrote parodic specimens that proved to be almost pure imitation; they attempted to duplicate the power of the original work by borrowing both form and subject matter. One essay attached to such a production began wistfully, "This is not, of course, a parody of Christina Rossetti's poem, 'Goblin Market.'" And, strictly speaking, what Sarah Sullivan achieved in her "Fruits of the Goblin Market" was not parody. ${ }^{5}$ Her interest in the original was primarily technical. She thought its prosody juvenile until she tried to duplicate it. Her much-shortened version of "Goblin Market" became an exploration of Rossetti's poetics, the kind of study we imagine the apprentice poet engaging in before adopting a style or inventing one. Here, for example, is Ms. Sullivan's description of the sound of the goblins as they approach the heroines of the poem, Lizzie and Laura:

\section{Softly it spoke, then grew insisting \\ Poured out of the woods, no longer whispering; \\ The source of the rumour came rattling bushes, Haphazard tumbling, stomping on rushes, \\ Feet that tromp, and weight that crushes}

These lines have their merit, but they are imitation, our primary interest in them being how closely they can approximate the original.

Once a student leaves the province of direct imitation (homage is not an inappropriate term), the relationship of original and derivative works grows more involved, even if we attend to only two variables within the parodic formula: variations of form and variations of subject matter. Among the most unusual parodies I received was one written by Scott Camp, a student fascinated by the skilled mechanics of a poem often mimicked in its own day, Tennyson's "Charge of the Light Brigade." Like Sarah Sullivan, Mr. Camp takes a primarily stylistic interest in his original, choosing to maintain Tennyson's well-known stanzaic form. But to this form he now applies a new subject matter-a battle between bephalumps and mice-that may reflect the Crimean sally, but which, in itself, is deliberately insignificant, its only purpose being to provide the verbal opportunities for drawing attention to the laureate's original structures. In a crude way, the parody analyzes poetic form the same way that Lewis Carroll's "Jabberwocky" explores the workings of language, by showing that structures themselves contain meaning. Camp's goal is to triumph ver-

${ }^{5}$ My students gave me permission to use their works provided that I mention them by name. 
bally within a predetermined form; his poem ultimately means nothing. The rejection of the conventional and anticipated elephants for the more intriguing bephalumps is the tipoff to the parodist's intentions:

$$
\begin{aligned}
& \text { Hephalumps, Hephalumps, } \\
& \text { Lots of 'em onward } \\
& \text { All in the valley of mice } \\
& \text { They stomped and they thundered. }
\end{aligned}
$$

In this second category of parody then, we have an exploration of form achieved through the imposition of subject matter that is new, but chosen to draw attention to the form, not to itself.

Closely related to the imitative variation just described is another in which a familiar form is explored (or recreated) by the adoption of a new subject matter that parallels that of the original. Here our intellects are engaged both by the familiarity of the original form and by the ingenuity of the parodist in hoisting a new matter onto it. In this species, the new subject is not designed to comment on form or on the appropriateness of the original theme. We may titter at the ludicrousness of the new materials being confined within the recognizable form, but we do not find fault with the original. Mr. Camp, who provided our example in the previous category, was inspired to write in this one as well, this time examining Browning's "How They Brought the Good News from Ghent to Aix" by dramatizing the fate of three youngsters trapped on a runaway merry-go-round. The lengthy parody fascinates by its inventive replications on a lower, comic plane (done appropriately in colloquial language) of the events of Browning's poem, Camp observing candidly at the end of his analysis of his own work: "If 'From Ghent to Aix' were to look solemnly into a warped mirror, it would see "A Ride Too Long' [his version] smiling back:"
After a while they cut off the lights,
But left us spinning on into the night.
I stared through the darkness but could not see
Even my hand in front of me;
With Pete at my shoulder and Doris behind,
Creepy night-thoughts flashed in my mind.

The fourth category of parody my students probed, like the previous one, reproduces the original form and substitutes a new matter. But now the matter is highlighted, the familiar form of the original being the device to achieve that end. This is, in fact, the category into which many familiar parodies fall-the familiar tune given new words, the familiar character given a new profession. The subject matter may, in a sense, parallel the original material, as in the previous category, but now the subject capitalizes on those parallels. It becomes significant in some way. A pertinent example of this type is provided by Britt Block in a Browning parody entitled, "Soliloquy of the Good Ol' Boy," in which an angry redneck spits venom at a hippie named Terrence:

At the meal we sit ... together:

"What's happening?" I must hear

Commie talk about the weather,

Pacificism, time of year.

"Not quite the crop we'd hoped for, scarcely

Dare we hope for extra sprouts? 
Is this organic or substitute parsley?"

I'd like to smash his organic snout.

The form of the "Spanish Cloister" is evident throughout as the good ol' boy rambles on, rather predictably, about God, Country, and the Flag before finally imagining, with some relish, the lynching of "that hippie kid." But then, in the very last line, the subject matter asserts itself over the form when we discover that the redneck replicating the hatred of Browning's monk is actually talking about his own child: "What a disgrace I have for a son!" For a moment at the end of the parody we forget Browning, and contemplate the impact achieved by the student's own analysis of an unfortunate human conflict. The form of the original provides the vehicle for an entirely new thought, paralleling (now that we think of it) the implied relationship between Browning's two monks, but also independent of that relationship.

If the subject matter can "free" itself from servitude to its original form, it is not surprising to find examples of subject matter turning on its former master. Indeed this is the type of parodic power most teachers expect students to achieve when given this assignment. (However, it should be abundantly clear by now that there are other legitimate explorations of an original possible within the imitative genre.) To the teacher of literature, the so-called "critical parody" is inherently the most intriguing because its interest and focus have become literary and its parodic energies self-contained.

Yet there are categories within the species of critical parody too, and my class produced at least three such varieties. The first deserving mention might actually belong in the previous group since, while it is a version of "Kubla Khan" that comments on Coleridge's creative process, its subject matter-the misfortunes of the man and not the foibles of the poet-stands slightly outside the interest of the original:

In Xanadu did Kubla Khan

A liquid pleasure dome decree;

Where opium, the sacred river ran

Through his veins time and time again,

Then he wrote his poetry.

Yet in his final couplet, Bob Marshall successfully fuses an interest in Coleridge's addiction with an awareness of the peculiarly visionary aspects of his poetry-and he does it with wit:

But what a miracle of rare device;

That he could write poetry and afford his vice.

Less playful and more involved in a critique of form and subject is another student's assault on what she regards as Tennyson's "supportive stand for military stupidity" in "The Charge of the Light Brigade." Marian Seitz cannot ignore the subject matter of this poem to explore the form, as Scott Camp did in the parody cited earlier. Instead, she capitalizes on our familiarity with the theme of the original (and its melodramatic rhythms) to give impact to her new version:

So does their memory fade

Quickly and undelayed.

Widows and orphans made

Cry in the night. 
If parody does, indeed, expand an original poetic vision to worlds or perspectives not previously included or contemplated, then we have Tennyson here taken sorely to task for ignoring a necessary part of his vision.

But critical parodies need not be so entirely serious, so socially conscious, or so outwardly directed. In fact, the most unified parody is one that will carry on its commentary largely within its own literary frame. Few students have the literary and theoretical sophistication to achieve such an effect, but at least one of mine did. In a piece entitled "Ms. Ulysses' Soliloquy" (with a significant pun in the Ms.), Frank Cook examines the not-so-subtle whoring that goes on between a work of art and the author/audience. The speaker in Cook's parody of the last chapter of Ulysses is the work itself, railing against Bloom-Dedalus-Joyce until, to quote the author, "she realizes that her destiny lies not with the man who created her but with those who shall read her and use her promiscuously in English papers." The following excerpts from "Ms. Ulysses" show what critical insight the student has achieved into the language and form Joyce uses and, not insignificantly, into the world that uses literary works:

Yes because he never did a thing like that before as trying to convince that critic from the times that even the typographic errors in Finnegans Wake were intentional while he was really too lazy to even tyrto do the proodf reading . . . how would I know what century this is since $i$ am art and thus immortal and eternal and without the least idea of when to get out of bed but $i$ long ages ago learned that all that eternity would be an endless succession of different and indifferent readers who would try to be pleased by me and some would only get it out and then leave limp having never gotten past the stately plump Leo and his burning kidney thats pornography if $i$ ever sat on the same shelf in dr. dandy's blue-light bookstore . . . i'm glad i have the omniscience $i$ do as being the whole novel and can comprehend myself in all of myself and see myself as what $i$ am and everything in me ... and dear dedalus with that girl by the shore and my how he wanted to be dedalus and how he fooled everyone into thinking he was so in his youth when he really was just a masturbating little fish-eater . . . it sometimes makes me wonder if he didn't use me to get ready get hot for. Finnegan and him a male and its that greek influence again but no he couldn't do that o yes he could o yes yess he could and o yessss oo o i'm oo yess o yess oooo i say yes $i$ think $i$ o yes i'm yes having yes an epiphany yes and yes $i$ will yes cut the nuts off the cheating bastard Yes.

It would be tempting to end this analysis of the range of parodic creation with Mr. Cook's achievement, but that would be to exclude a species of parody that includes Joseph Andrews in its number-the work that begins as parody but discovers sufficient energies of its own to lay claim to independent artistic existence. I did not anticipate finding a Joseph Andrews in my collection of student work, but neither was I surprised to discover two pieces in which the primary interest was to be found outside the traditional limits of parody. Yet even these two works differed significantly.

Robert Leon intended to shape his parody on Browning's "Prospice," using the familiar form and syntax of the poet's reflection on the death of his wife as the vehicle for his portrait of a young man struggling "to find strength to confront the object of his love." The borrowing from Browning is so effortless that the reader is not prone to laugh at either the parody or Browning, or, for that matter, even to think of Browning. Mr. Leon's work is a poem in the Browning style, not a parody at all. Yet as a response to an original, the student's perhaps inordinately impas- 
sioned verses are as successful (if less literarily self-conscious) than the previously cited poke at Joyce:

Fear love? - to feel the lump in my throat,

The flush on my face,

When the day begins, and the bells denote

She'll be in her place,

The last heavy sigh, the rush from the dorm, I hasten to go

Where she stands, the coed with her Aphrodite charm Who will sit in my row.

Although, as required by the assignment, the poem is followed by an analysis designed to explain the relationship of parody to original, and although the student pursues the analysis with the tenacity of a Pinzgauer, the real impulse behind the poetic effort is not disguised much.

The last response to this particular assignment I feel compelled to present is actually a satire containing within it a series of stylistic parodies. The larger satiric frame within which the multitude of parodies is housed is explained by the use to which the parodies are put: they are designed to reflect an eighteenth-century attitude toward nineteenth-century poetry. The supposed author, a crusty Georgian man of letters by the name of Blogg, is miraculously transported to Regency, then Victorian, and finally modern England (this translation recalling the flight of poor Southey in Byron's "The Vision of Judgment"), where he is led to comment on the state of contemporary poetics in the verse form he finds, by contrast, so rational and appealing, the heroic couplet. This description of Michael Ambrose's satiric framework suffices to show that while his initial impulses may have been parodic, his desire to mock the poetic of an entire age (I should say an entire course) led him to adopt a formal structure necessarily more encompassing than any one poetic style. Perhaps borrowing from Dryden's definition of the genre in A Discourse Concerning the Original and Progress of Satire, Ambrose's lengthy piece is styled an "Epick."

In the course of the poem's three hundred lines, the persona's staunchly Augustan intellect makes fritters of Romantic, Victorian, and Modern poetry. The achievement is fully satiric although Ambrose never abandons the peculiar concern of parody with individual form and subject matter. Indeed, part of the delight of the work is watching distinctive styles being controlled, intermeshed with and comically mangled by the overriding couplet form. With great self-restraint, I quote only two selections from this rapier work. In the first, Sir Blogg encounters a melancholy, inebriated Tennyson, stewing in a tavern, lamenting his awesome burden as England's first man of arts:

"It little profits that an idle muse

Should lie thus supine, with no real use;

No argent verse declaimed, no aureate,

No poems to show-and the new Laureate!

I tell thee, Sir, 't is not an easy task

To cloak commonplaceness with verséd mask.

Take, now, this unassuming emporium.

Could mortal make of it an In Memoriam?

Beside this dross were 'Enoch's ocean spoil'

The fruit of single passing moment's toil. 
Take, take, take an image already taken-

Such as the sea, a crannied wall, a kraken-

You'll find amidst dull uniformity

The dormant seeds of poetic enormity.

But let us then cross over to the bar,

And compose poems of places near and far.

Made weak by time and drink, yet all in all

I'll strive, to seek, to find, ere drunken fall."

I doubt Tennyson takes a better drubbing anywhere in Hamilton's ample collection. Yet Mr. Ambrose tops himself with Blogg's censorious report of another bard reading from "Some work he called, I think, Waste Land-_"

\footnotetext{
"April is the cruelest wench, breeding

Broods of braying brats from one deeding;

Her time ill-spent with hyacinth and root

That spring rain (N.B.: Anglo-Saxon regn

And origins in the Greek which I'll not deign

to elaborate) fell covering snow

Winds chatter here, there, below I know

Heigh-ho! Shantib, Shantib, Auntie (N.B.:

Vide amite Virgo ergo sum, you see)

And nicht waar? Waaroom? Bar-rooms are

Not the proper place for Apollo's car,

Which struck the by-stander in the Unreal City

Last week. Fra Lippo sang a mordant ditty,

Dactyls, Axles, Tractors, pentameter

Fell from hence, year to year the scimitar

Disclosed the Park in the dark where lark

And Day's Work Tobacco did hit the mark.

Shantib-Shantib-Shantytown is all brown

And down; the clown I used to know a draper

Who wrote a modern poem he called Waste Paper

And so believed in weather, whether or not

He'd had the sense, he'd not, I say he'd not!"
}

For Michael Ambrose, the assignment to write a parody became, in effect, the near occasion for his own highly original, complex, and hilarious reflection on postAugustan poetics. It may be argued that in his use of the couplet form and the persona of Blogg, he adopts an essentially dependent relationship to an entire satiric tradition, and that is probably true. But Ambrose uses the conventions of eighteenth-century verse satire, anachronistic as they may be, as a way of creating a necessary distance between the targets of his satire and his audience's predictably post-romantic sympathies. Sir Blogg's Epick, like a true parody, feeds off the particular, recognizable (even cherished) idiosyncrasies of the noteworthy at the same time that it poses an entirely different poetic tradition as an alternative or complement to romantic and modern aesthetic assumptions. But it borrows so widely, energetically, and, most important, with such integrity within its own design that it detaches itself from the particular ties of parody.

Parody is a literary form as capacious as any other. The teacher who motivates students to explore a literary original through the exploitation of form and subject matter that parody encourages should be prepared for a wide variety of responses. For an original work and its parodies are like planet and satellites. Centripetal forces 
of imitation draw a derivative work downward toward the usually more powerful, more massive original while centrifugal forces of creation and originality (forces operating in any literary construct) push the parody outward to a higher orbit or, given sufficient energy, from orbit entirely. There is no single, ideal relationship between an original and an imitative work; around any literary body there can be numerous satellites at different orbital levels, representing unique balances between the forces of imitation and creation. What this paper has attempted to show is that, given the necessary freedom and an instructor who understands the dynamics of imitative forms, students will explore a variety of legitimate parodic relationships of significant critical interest. At the same time, they will produce works and commentary that are potentially more instructive about the themes, character, and craft of the literature they have studied than the conventional term paper. And vastly more entertaining.

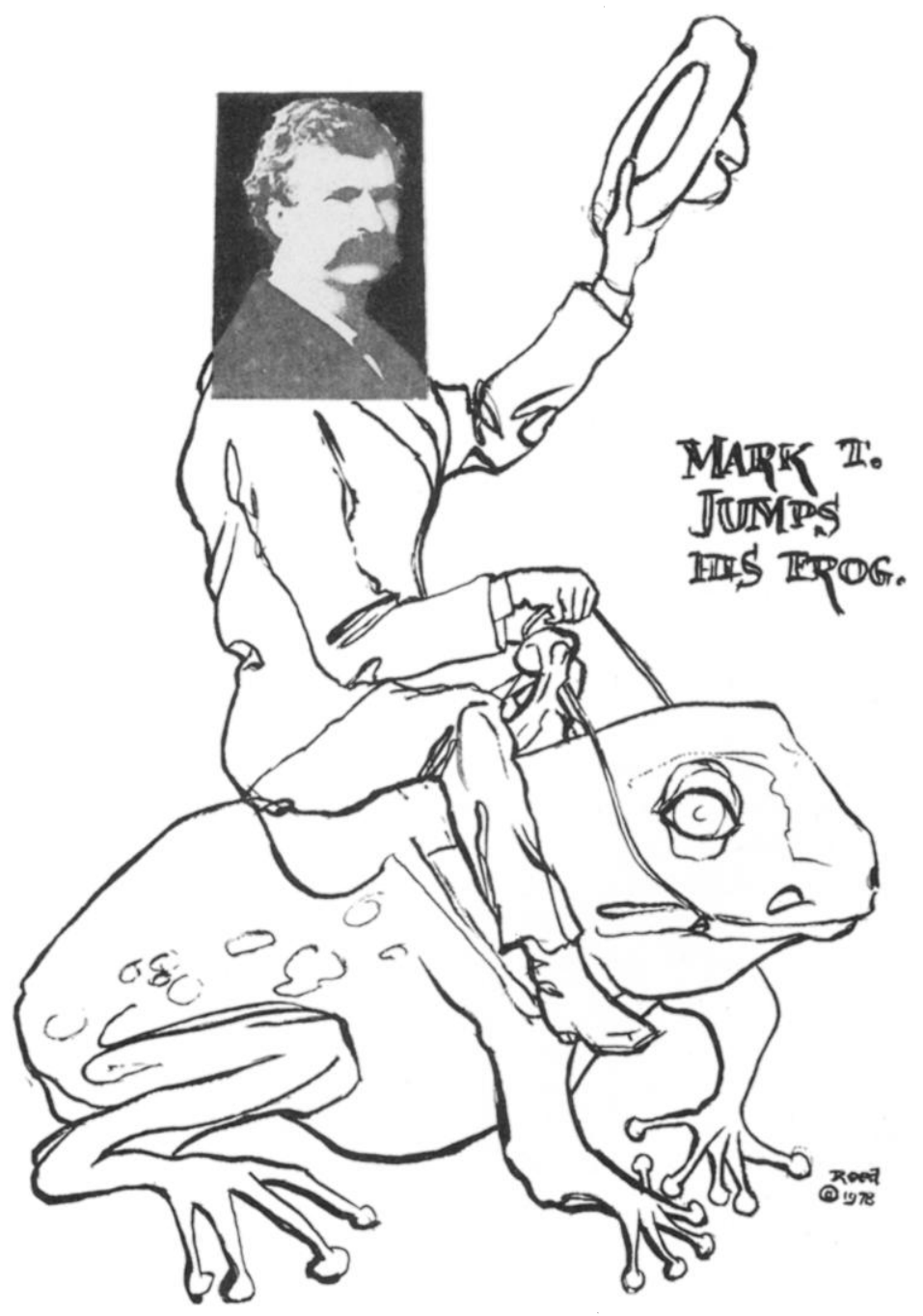

